\title{
Ball-Milling Strategy for Epimerization-Free Peptide Synthesis
}

\section{Key words}

ball milling

epimerization

peptide synthesis

mechanochemistry

\section{Synifact
of the Month}

\begin{tabular}{|c|c|c|c|}
\hline Product & time (min) & isolated yield (\%) & de $(\%)$ \\
\hline Z-Ala-Phg-Phe-OMe & 20 & 89 & $>99$ \\
\hline Z-Ala-D-Phg-Phe-OMe & 20 & 92 & $>99$ \\
\hline Z-Ala-Cys(Bn)-Ala-OMe & 30 & 98 & $>99$ \\
\hline Z-Ala-Cys(Bn)-Phe-OMe & 20 & 94 & $>99$ \\
\hline Z-Phe-Val-Cys(Bn)-OMe & 30 & $98^{\mathrm{a}}$ & $>99$ \\
\hline Z-Phe-D-Val-Cys(Bn)-OMe & 30 & 97 & $>99$ \\
\hline Z-Phe-Val-Ser(t-Bu)-Ot-Bu & 30 & $97^{\mathrm{a}}$ & $>99$ \\
\hline Z-Phe-D-Val-Ser(t-Bu)-Ot-Bu & 20 & 97 & $>99$ \\
\hline Boc-Trp-Phe-Glu(Bn)-OBn & 15 & 92 & $>99$ \\
\hline Boc-Trp-Phe-Gly-OBn & 10 & 84 & $>99$ \\
\hline Boc-Trp-D-Phe-Gly-OBn & 10 & 95 & $>99$ \\
\hline Z-Phe-Val-Leu-Leu-OBn & 25 & $95^{\mathrm{b}}$ & $>99$ \\
\hline Z-Phe-Val-Leu-Leu-Leu-OBn & 30 & $93^{b, c}$ & $>99$ \\
\hline Z-Phe-D-Val-Leu-Leu-Leu-OBn & 30 & $91^{\mathrm{b}, \mathrm{c}}$ & 99 \\
\hline
\end{tabular}

Significance: Because of the large demand for peptides in various fields, chemists are actively searching for highly efficient and epimerizationfree methods for peptide synthesis. The authors have developed a method involving ball milling for synthesizing peptides in high yields and with minimal epimerization.
Comment: The developed ball-milling strategy for coupling in which peptide fragments containing highly epimerization-prone and hindered amino acids at the C-terminus actively participate in the reaction to afford the desired peptides in high yields with excellent purity. This method requires a very small amount of solvent. 